\title{
The progress on physicochemical properties and biocompatibility of tantalum-based metal bone implants
}

\author{
Huiling Li ${ }^{1}$ - Zhigang Yao ${ }^{1}$ Jian Zhang $^{2} \cdot$ Xinjia Cai $^{1} \cdot$ Long Li $^{1}$ - Gui Liu ${ }^{1}$ Junjie Liu ${ }^{1}$ Lin Cui ${ }^{1}$ Junhui Huang ${ }^{1}$
}

Received: 16 December 2019 / Accepted: 10 March 2020 / Published online: 16 March 2020

(c) Springer Nature Switzerland AG 2020

\begin{abstract}
Repair, reconstruction, and replacement of congenital malformations, either in case of exogenous or iatrogenic tissue and organ defects, requires utilization of a large number of personalized biomaterials. In recent decades, the improvement of people's quality of life and the prolongation of life expectancy have promoted the development of medical and material science. In addition to the traditionally used stainless steel, other materials such as cobalt-chromium alloy, pure titanium, titanium alloy, and the newly alloy materials continue to emerge, such as tantalum-based alloy materials which have been used in clinic, especially the application of porous tantalum trabecular metal in orthopedics. This paper which has provided good preliminary works for the development of tantalum biomaterials with more advantages in the future such as tantalum dental implants summarizes in detail the progress of tantalum materials in physicochemical properties and biocompatibility in recent years. From the comparison of surface passivation films of different metals in different environments, the electrochemical corrosion behavior of tantalum, the release of different metal ions and the damage to cells, it is concluded that tantalum has excellent corrosion resistance. Besides, the excellent biocompatibility of tantalum metals concluded by cytology, molecular biology, protein adsorption experiment, and hematology experiment, as well as regular follow-up observation of patients with porous tantalum trabecular metal in clinic. The excellent corrosion resistance and biocompatibility of the tantalum metal have a very wide prospect in clinical application.
\end{abstract}

Keywords Tantalum-based metal bone implants · Passivation film - Corrosion resistance - Physicochemical properties . Biocompatibility · Porous tantalum trabecular metal

$\begin{array}{llll}\text { Abbreviations } & \text { OCP } & \text { Open circuit potential } \\ \text { Ta } & \text { Tantalum } & \text { EIS } & \text { Electrochemical impedance spectroscopy } \\ \text { PTTM } & \text { Porous tantalum trabecular metal } & \text { r-SBF } & \text { Revised simulated body fluid } \\ \text { ISO } & \text { International Organization for } & \text { RP } & \text { Polarization resistance } \\ & \text { Standardization } & \text { SBF } & \text { Simulated body fluid } \\ \text { SS } & \text { Stainless steel } & \text { ROS } & \text { Reactive oxygen species } \\ \mathrm{Ti} & \text { Titanium } & \text { TLR-4 } & \text { Toll-like receptor 4 } \\ \mathrm{Nb} & \text { Niobium } & \text { Tf } & \text { Transferrin } \\ \text { SLS } & \text { Selective laser sintering } & \text { TfR } & \text { Transporter receptors } \\ \text { XPS } & \text { X-ray photoelectron spectroscopy } & \text { BMP } & \text { Bone morphogenetic protein } \\ \text { PEEK } & \text { Polyether ether ketone } & \text { ALP } & \text { Alkaline phosphatase } \\ \text { rBMSCS } & \text { Rabbit bone marrow mesenchymal stem cells } & \text { NPS } & \text { Nanoparticles }\end{array}$

$\triangle$ Junhui Huang, 808003@csu.edu.cn | ${ }^{1}$ Hunan Key Laboratory of Oral Health Research \& Hunan 3D Printing Engineering Research Center of Oral Care \& Hunan Clinical Research Center of Oral Major Diseases and Oral Health \& Xiangya Stomatological Hospital \& Xiangya School of Stomatology, Central South University, Changsha, Hunan 410008, China. ${ }^{2}$ Z-BEST Dental Science \& Technology Co. Ltd, Changsha, Hunan, China. 


$\begin{array}{ll}\text { BMMSCs } & \text { Bone marrow mesenchymal stem cells } \\ \text { AFM } & \text { Atomic force microscope } \\ \text { VPS } & \text { Vacuum plasma spraying } \\ \text { HMSCs } & \text { Human mesenchymal stem cells } \\ \text { PVD } & \text { Plasma vapor deposition } \\ \text { OPN } & \text { Osteopontin } \\ \text { OC/OCN } & \text { Osteocalcin } \\ \text { BSA } & \text { Bovine serum albumin } \\ \text { LYS } & \text { Lysozyme } \\ \text { QCM-D } & \text { Quartz crystal microbalance } \\ \text { ECAP } & \text { Equal channel angular pressing } \\ \text { BCC } & \text { Body-centered cubic } \\ \text { CVD } & \text { Chemical vaporous deposition } \\ \text { THA } & \text { Total hip arthroplasty } \\ \text { AOFAS } & \text { American orthopedic foot and ankle score } \\ \text { ACDF } & \text { Anterior cervical discectomy and fusion }\end{array}$

\section{Introduction}

Since the development of the world tantalum(Ta) industry in the 1920s [1], Ta has been continuously developed in the application field due to its high melting point (up to $2995^{\circ} \mathrm{C}$ ), good chemical stability, corrosion resistance and high density $\left(16.68 \mathrm{~g} / \mathrm{cm}^{3}\right)$, widely used in electronics, chemical industry, aviation and weapon systems [2]. In the 1940s, pure Ta was first applied in medical treatment, and its stable biological characteristics also made Ta play an important role on medical treatment, including Ta wire for suture in surgical incision, Ta stent implants for vascular stenosis, Ta nails in early osteonecrosis of the thigh bone, Ta rods for supporting bone defect and porous tantalum trabecular metal (PTTM) used in joint and spinal surgery [3-8], which demonstrate good results.

The medical application of $\mathrm{Ta}$ is closely related to its biocompatibility. At present, the evaluation of biocompatibility of biomaterials mainly involves compliance with the requirements stipulated by the International Organization for Standardization (ISO) 10993 and National Standard GB/T16886, through a series of experiments-in vitro and in vivo. In vitro experiments, such as cytology, protein adsorption, hematology, and molecular biology experiments, can help to understand the relationship between biomaterials and tissue cells. On the other hand, in vivo experiments assisting in analyzing whether the biological behavior of biomaterial is compatible with the dynamic environment of the human body, involving tests such as systemic toxicity, immunology, subcutaneous, and bone-implant test. The researchers can choose these experimental methods according to their purpose, a series of experimental evaluations will determine whether the material is biosecurity and functional, that is to say, the material does not have a toxic effect on the human body and does not cause host heterogenic recognition reaction. At the same time, biomaterials are required to exercise their corresponding functions in specific applications, not to be rejected and destroyed, to maintain their original physical, chemical, mechanical and biological properties, and to form a good combination with the host for a long time finally.

\section{Physicochemical properties of Ta and its advantages in medical applications}

The traditional bone implant materials mainly include stainless steel (SS), cobalt-based alloy and titanium(Ti) alloy [9]. SS has good mechanical strength and corrosion resistance, but it will also be corroded in a specific environment in the body, also, added elements such as $\mathrm{Cr}$ and $\mathrm{V}$ in SS have certain metal toxicity. Cobalt-based alloy (CoCrMo alloy, CoCrNiMo alloy) is a kind of material widely used in the clinic, it has high fatigue strength, tensile strength, and excellent corrosion resistance, it is mainly used for replacement of bone joint prosthesis, such as knee joint and hip joint replacement prosthesis. Although cobalt-based alloy materials have good clinical effects, there are problems such as high elastic modulus, low friction characteristics, and potential toxicity of $\mathrm{Co}, \mathrm{Cr}$, and other metals [10]. Therefore, it is not suitable to make scaffold materials with guiding bone tissue growth. Ti alloy has good corrosion resistance, biocompatibility and has a large density and elastic modulus, which is widely used in medical biomaterials implanted devices manufacture [11]. However, Ti and its alloys have limited internal life, high activity, easy oxidation, and difficult processing. It is found that Ta has the elastic modulus and biocompatibility matching with human bone tissue, and can meet the requirements of bone tissue substitute materials [12]. Heiner et al. [13] found that Ta has a high bending strength. The Ta-based metal biological material can provide effective support for tissue growth due to good durability and corrosion resistance after being implanted in the living tissue, and it is a permanent biological medical material implant with good biocompatibility [14]. Yuan et al. found that $\mathrm{Ta}$ and Niobium( $\mathrm{Nb}$ ) alloys have better biocompatibility than Ti alloys in organisms and can better meet the requirements of biomaterials [15]. we [16, 17] applied Ta to the preparation of dental materials and repairation of human hard tissue defects in the early stage, carried out a series of studies, and made a good breakthrough. At the same time, using 3D printing technology to prepare Ta dental crown and selective laser sintering (SLS) 


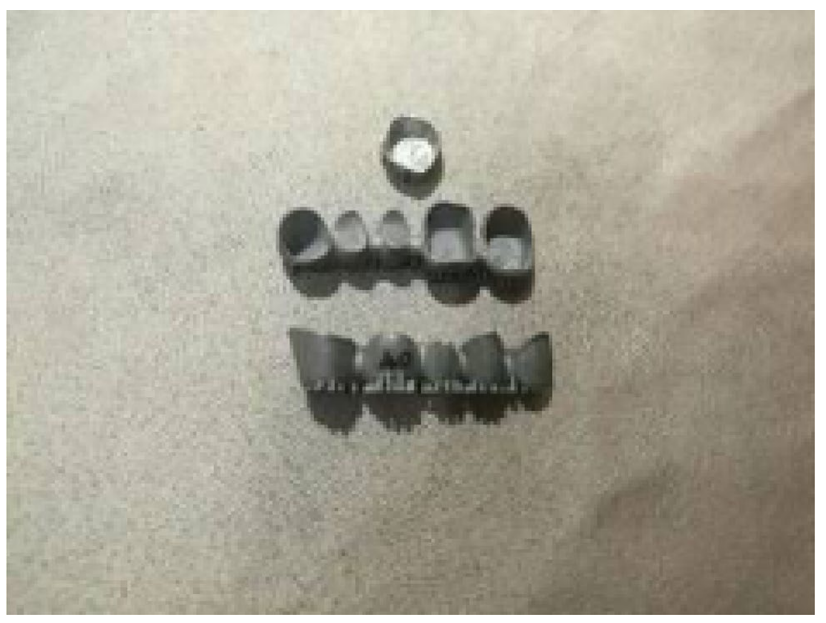

Fig. 1 3D printing of Ta alloy dental crown

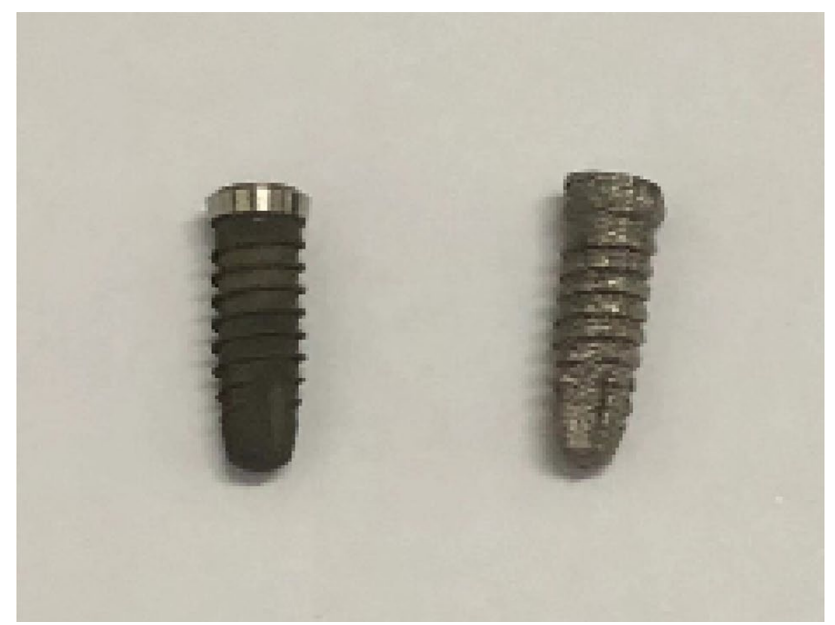

Fig. 2 The implant on the right in the picture is 3D printing of tantalum-niobium alloy dental implant primitive form; The dental implant on the left is the commonly used Ti alloy in clinic

to prepare dental implants, obtaining accurate and rapid processing methods, see Figs. 1 and 2.

\section{Corrosion resistance of Ta and mechanism of cell damage induced by metal ions}

\subsection{Ta metal has a stable passivation oxide film}

The excellent corrosion resistance of biomaterials is a necessary condition for implantation into the human body, which has an important influence on the properties of implantable materials. The primary factor related to corrosion resistance is the formation of surface passivation oxide film, which can hinder the release of metal ions from the substrate, thus preventing its adverse reaction to tissue cells. No matter what kind of metal has corrosion tendency in thermodynamics, these passivation films will minimize corrosion. Table 1 lists the composition and properties of passivation films on different metals and alloys surface and the release of metal ions in different liquid environments.

It can be seen from the table that the chemical composition, stability, and compactness of these metal materials affect the release of metal ions under different conditions in vitro, and then affecting the biological function of the materials. X-ray photoelectron spectroscopy (XPS) and spectral measurements can be used to analyze the chemical composition of the oxide layer on the metal surface, the semi-maximum value of the oxygen signal can be used to estimate the thickness of the oxide layer on the surface of the sample [19]. Many references have proved that the passivation oxide film on Ta surface is very stable and has high corrosion resistance, and no corrosion signs have been found in physiological solution in vitro $[12,18,19]$. The results show that the Ta oxide thin films prepared in the oxidation atmosphere are in a stable +5 valence state, However, the phase stability of $\mathrm{Ta}_{2} \mathrm{O}_{5}$ is also related to different crystal forms, and the $B$ phase structure composed of deformed octahedral is stable dynamically $[36,37]$. Many studies have added $\mathrm{Ta}_{2} \mathrm{O}_{5}$ to other materials or prepared them into thin films to improve the biological properties of the materials. For example, the addition of Ta pentoxide to polyether ether ketone (PEEK) has also been found to improve surface roughness, hydrophilicity, surface energy and protein absorption of $\mathrm{PEEK} / \mathrm{Ta}_{2} \mathrm{O}_{5}$ composites [38]. $\mathrm{Ta}_{2} \mathrm{O}_{5}$ nanotube film displays good cellular compatibility with rabbit bone marrow mesenchymal stem cells (rBMSCs) and promotes the expression of the osteogenic genes [39]. It was found that the corrosion resistance of Ti decreased when the concentration of fluoride was high and the acid $\mathrm{PH}$ exposed to fluorine ions for a long time, when the PH was 4.5 and the mass fraction of $\mathrm{NaF}$ was $0.3 \mathrm{wt} \%$, the detected Ti content was $0.6-3.4 \mathrm{ug} / \mathrm{g}$. When $0.6-1.0 \mathrm{wt} \% \mathrm{NaF}$ was contained, the Ti content increased significantly to $25-74 \mathrm{ug} / \mathrm{g}$ [23]. Other studies have shown that the corrosion resistance of industrial pure $\mathrm{Ti}(\mathrm{CP})$ and $\mathrm{Ti} 6 \mathrm{Al} / \mathrm{V}$ in artificial saliva containing 227 ppm and 12300 ppm F-decreases, CP Ti degrades due to pitting corrosion, Ti6Al4V has general corrosion and microcracks [26]. Also, the corrosion resistance of $\mathrm{Ti}$ in other liquid solutions is excellent. Semi-conductive or non-conductive oxide protective layers are formed on both Ta and Ti surfaces to prevent electronic exchange, thus preventing redox reactions on the surface [40]. And the corrosion resistance of the $\mathrm{Ni}$ is poor, the stability of the surface film $\mathrm{NiO}$ is low, and a large amount of $\mathrm{Ni}$ ions can be released in a short time $[27,28]$. In most cases, the 
Table 1 Composition, the stability of passivation films and release of metal ions on different metals under different conditions

\begin{tabular}{|c|c|c|c|c|}
\hline Metal type & $\begin{array}{l}\text { Surface passivation film composi- } \\
\text { tion }\end{array}$ & Surface passivation film stability & Metal ions release & References \\
\hline \multirow[t]{3}{*}{ Ta } & Air: $\mathrm{Ta}_{2} \mathrm{O}_{5}$, Thickness: $3.0 \mathrm{~nm}$ & Stable & - & {$[12]$} \\
\hline & SBF: Ta oxide and hydroxide & $\begin{array}{l}\text { There is no evidence of corrosion } \\
\text { on the surface }\end{array}$ & - & [18] \\
\hline & R-SBF: Mainly $\mathrm{Ta}_{2} \mathrm{O}_{5}$ & $\begin{array}{l}\text { high chemical stability, better than } \\
\mathrm{Nb}_{2} \mathrm{O}_{5}\end{array}$ & - & [19] \\
\hline \multirow[t]{6}{*}{$\mathrm{Ti}$} & Air: $\mathrm{TiO}_{2}$, thickness $1.5-10 \mathrm{~nm}$ & stable & - & {$[20,21]$} \\
\hline & $\begin{array}{l}\text { Acid solution and High fluoride } \\
\text { concentration }\end{array}$ & Corrosion resistance of Ti decreased & Ti content increased significantly & {$[22,23]$} \\
\hline & Artificial saliva: $\mathrm{TiO}_{2}$ & Stable passive behavior & - & {$[24]$} \\
\hline & Lysozyme: $\mathrm{TiO}_{2}$ & Stable passive behavior & - & {$[24]$} \\
\hline & Artificial bone fluid: - & stable & The Ti content is negligible & {$[25]$} \\
\hline & $\begin{array}{l}\text { Artificial saliva }+ \text { High concentration } \\
\text { of } \mathrm{F}^{-} \text {: Existing porous state }\end{array}$ & Oxide film defect & High release of $\mathrm{Ti}$ ions & {$[26]$} \\
\hline $\mathrm{Cr}$ & $\mathrm{Cr}_{2} \mathrm{O}_{3}$ in most cases & $\begin{array}{l}\text { Equivalent to SS surface film, more } \\
\text { stable }\end{array}$ & - & {$[27]$} \\
\hline $\mathrm{Ni}$ & Compound $\mathrm{Ni}(\mathrm{OH})_{2} / \mathrm{NiO}$ & $\begin{array}{l}\text { The protection ability of the surface } \\
\text { membrane is poor }\end{array}$ & $\begin{array}{l}\text { The initial ions release rate is very } \\
\text { high }\end{array}$ & {$[27,28]$} \\
\hline \multirow[t]{7}{*}{ SS } & $\begin{array}{l}\text { Physiological saline: High content } \\
\text { of } \mathrm{Fe}, \mathrm{Cr} \text {, and } \mathrm{Mo} \text {, Low content } \\
\text { of } \mathrm{Ni}\end{array}$ & Relatively stable & $\begin{array}{l}\text { Nickel release is higher than Fe } \\
\text { and } \mathrm{Cr}\end{array}$ & [29] \\
\hline & SBF: $\mathrm{Cr}$ and Fe oxides & - & & {$[30]$} \\
\hline & Acidity (PH4.5): rich $\mathrm{Cr}$ & - & $\begin{array}{l}\text { The release rate of Iron and } \mathrm{Ni} \text { is } \\
\text { lower than that of pure metal, } \\
\text { while the release rate of } \mathrm{Cr} \text { is the } \\
\text { same as that of pure metal }\end{array}$ & {$[27]$} \\
\hline & $\begin{array}{l}\text { High } \mathrm{PH}: \mathrm{Cr} \text { goes down, } \mathrm{NiO} \text { goes } \\
\text { up }\end{array}$ & $\begin{array}{l}\text { Lead to the degradation of a pas- } \\
\text { sive film }\end{array}$ & Cr concentration goes up & {$[31]$} \\
\hline & $\begin{array}{l}\mathrm{H}_{2} \mathrm{O}_{2}+\text { Physiological saline: Iron } \\
\text { oxide, } \mathrm{CrOOH}, \mathrm{Cr}_{2} \mathrm{O}_{3}\end{array}$ & It can't act as a corrosion barrier & $\begin{array}{l}\text { Ni release was significantly higher } \\
\text { than Iron and } \mathrm{Cr}\end{array}$ & [29] \\
\hline & Albumin + saline: $\mathrm{Fe}_{2} \mathrm{O}_{3}$ and $\mathrm{FeOOH}$ & Thin oxide film & Promote the release of Iron and $\mathrm{Cr}$ & [29] \\
\hline & Ringer's physiological solution & $\begin{array}{l}\text { n-type and p-type double-structure } \\
\text { high-defect section passivation } \\
\text { film }\end{array}$ & - & {$[31]$} \\
\hline \multirow{4}{*}{$\begin{array}{l}\text { Cobalt-Chro- } \\
\text { mium base } \\
\text { alloy }\end{array}$} & $\mathrm{H}_{2} \mathrm{O}_{2}+\mathrm{PBS}: \mathrm{Cr}$ & Relatively stable & Co preferential release & {$[32]$} \\
\hline & $\begin{array}{l}\text { PBS: } \mathrm{Cr} \text { oxide; With the increase of } \\
\text { potential, } \mathrm{Cr}(\mathrm{III}) \text { can be converted } \\
\text { into } \mathrm{Cr}(\mathrm{VI}), \mathrm{Co} \text { (II) to } \mathrm{Co} \text { (III) }\end{array}$ & - & - & {$[32,33]$} \\
\hline & $\begin{array}{l}\text { Air: Molybdenum oxide (IV) and } \mathrm{Cr} \\
\text { oxide (III) }\end{array}$ & Relatively stable & - & {$[34]$} \\
\hline & $\begin{array}{l}\text { PBS-HA: Low polarization, } \\
\mathrm{Cr}(\mathrm{III}) \text { plays a major role; High } \\
\text { polarization, } \mathrm{Cr}(\mathrm{VI}) \text { and } \mathrm{Mo}(\mathrm{VI}) \\
\text { play a major role }\end{array}$ & Relatively stable & After polarization, Co dissolves first & {$[35]$} \\
\hline
\end{tabular}

surface of SS and Cobalt-Chromium-based alloy forms a Chrome-rich oxide film, $\mathrm{Cr}_{2} \mathrm{O}_{3}$ has high corrosion resistance, which can protect the matrix from corrosion to a certain extent, However, in some other cases, such as the co-presence of hydrogen peroxide and albumin, the corrosion of SS can be accelerated, surface oxidation layer exists as corrosion products. The composition of oxide film
Cobalt-Chromium alloy formed in a solution is also related to the potential. With the increase of potential, $\mathrm{Cr}$ (III) can be converted into $\mathrm{Cr}(\mathrm{VI}), \mathrm{Co}(\mathrm{II})$ to $\mathrm{Co}(\mathrm{III})[32,33]$. Therefore, as the potential increases, the composition of oxide film on the metal surface tends to change to a higher price to achieve stability. In a word, in terms of the protective properties of the passivation film, Ta has a very stable 
passivation oxide film, which can protect the substrate from corrosion to the maximum extent.

\subsection{Electrochemical corrosion behavior characterizes the corrosion resistance of Ta}

The corrosion resistance of the implantation can be characterized by electrochemical corrosion behavior, such as open circuit potential (OCP), potentiodynamic polarization test, electrochemical impedance spectroscopy (EIS) and so on, the test results of these indexes are closely related to the corrosion resistance of implanted metal materials. Studies have shown that in the revised simulated body fluid ( $r$-SBF), the EIS measurement results show that the curvature radius of the capacitor ring of pure Ta is greater than $\mathrm{Nb}-60 \mathrm{Ta}-2 \mathrm{Zr}$ and pure $\mathrm{Nb}$, indicating that pure $\mathrm{Ta}$ has a high polarization resistance (RP), and the passivation film grown on the surface has a stronger protective effect, the OCP measurements value moved to the positive side, where anodic dissolution occurred and an oxide film was formed [19]. Breakdown potential is the lowest potential for pitting/gap corrosion initiation and propagation, the measurement results show that the breakdown potential of 316L SS and 1605 Cobalt-Chromium alloy wire is $1.03 \vee$ and $0.43 \vee$ respectively, even though the potential of pure Ta reaches $1.6 \mathrm{~V}$, there is no local corrosion, which indicates that pure Ta has a high resistance to pitting corrosion [41]. Zitter et al. measured the current density of metals in saline with a stable rapid redox system, the results also showed that Ta had the lowest value, while SS and Cobalt alloy showed the highest current density [40]. The higher the RP value, the lower the corrosion current density (Icorr), and the better the corrosion resistance of the metal. Bermudez [42] studies have shown that Ta also has very good corrosion resistance in a strong acid environment (the stability second only to the surface oxide layer), compared with Ti and SS implant materials at the same time, there are no obvious changes in weight or toughness. In simulated body fluid (SBF), Ta films formed by substrate bias of $-100 \mathrm{~V}$ and $-200 \mathrm{~V}$ are mainly a mixture of $\beta$ phase and a few a phases [18], it has been shown that $\beta$-Ta (Metastable tetrahedral) has higher hardness and good contact damage resistance, while $\alpha-T a$ (body-centered cubic) is more plastic [43-45], so the Ta membrane is stable. A high amount of Ta $(>6 \%)$ added into the alloy can make the $\mathrm{Ta} 2 \mathrm{O} 5$ structure on the surface of MoTa alloy more compact, reducing the gap between cations, and improving the corrosion resistance [46]. The characterization of electrochemical corrosion behavior further confirms the stability and high resistance to pitting corrosion of Ta oxide films in different liquid environments.

\subsection{Different metal ions can induce cell damage}

Once the amount of metal ions released by corrosion under different conditions exceeds the tolerance limit of cell tissue, a series of pro-inflammatory reactions will be triggered. These metal ions released by corrosion induce the cells to produce reactive oxygen species (ROS), which then initiate a series of signal transduction processes. The process of different metal ions inducing cells to produce pro-inflammatory mediators is related to Toll-like Receptor 4 (TLR4), p 38 mitogen-activated protein kinase and nuclear factor pathways [47-49], it can be said that oxidative stress leads to the generation of ROS, which is a key stimulant to activate these pathways. A kind of metal ion can activate a variety of intracellular signaling pathways to mediate the release of cytokines, promote local inflammatory responses, and initiate mitochondrial-mediated apoptosis. Figure 3 illustrates the specific mechanism of ROS production induced by metal ions with iron ions as an example. $\mathrm{Fe}^{3+}$ first binds to transferrin (Tf) in the blood and then recognized and bound by transporter receptors (TfR) on the surface of the cell, $\mathrm{Fe}^{3+}$ is released into the cytoplasm in the form of the endosome, after that, a series of redox reactions led to the production of ROS, which leads to oxidative stress $[50,51]$. (1) reaction is considered to be a chemical reaction called Fenton reaction, which catalyzes the conversion of hydrogen peroxide $\left(\mathrm{H}_{2} \mathrm{O}_{2}\right)$ to active hydroxyl radical (HO) [52]. (2) Metal ions also reduce the activities of antioxidant enzymes such as superoxide dismutase, catalase, and glutathione peroxidase, increasing lipid peroxidation, reducing the ability of cells to eliminate free radicals, significantly increasing the oxidative stress of mitochondria and the level of protein carbonylation, thus further damaging the antioxidant capacity of cells $[53,54]$. Studies have shown that $\mathrm{Co}(\mathrm{II}), \mathrm{Ni}(\mathrm{II})$ and $\mathrm{Cr}(\mathrm{III})$ can significantly reduce cell vitality and cause pathological changes such as cell contraction, shedding, vacuole and swelling, apoptotic cells increased mostly in Co(II) exposure, and cell necrosis was predominant in $\mathrm{Ni}(\mathrm{II})$ exposure [53-56]. Co(II) can significantly reduce the movement ability of macrophages and inhibit cell migration by RhoA downregulation and cytoskeleton reorganization, which is still happened by the emergence of ROS [57]. Ni ions gradually accumulated in cells also affect the ability of bone morphogenetic protein (BMP-2) to induce alkaline phosphatase (ALP) formation $[58,59]$. Some studies have shown that compared with Nitinol, the surface layer rich in Ti or Ta can significantly reduce the formation of ROS and longevity protein free radicals [60]. Qiao et al. found that among the concentrations of metal ions causing DNA damage in vitro, $\mathrm{Cr}$ (III), $\mathrm{Fe}$ (II) and $\mathrm{AI}(\mathrm{III})$ were $50 \mu \mathrm{M}$, while Ni(II) $10 \mathrm{uM}$ could cause DNA damage, so different metal ions with the same concentration had different toxic effects on cells [61]. The 
Fig. 3 The specific mechanism of ROS production induced by metal ions with iron ions as an example [50-54]

\section{oxidative stress}
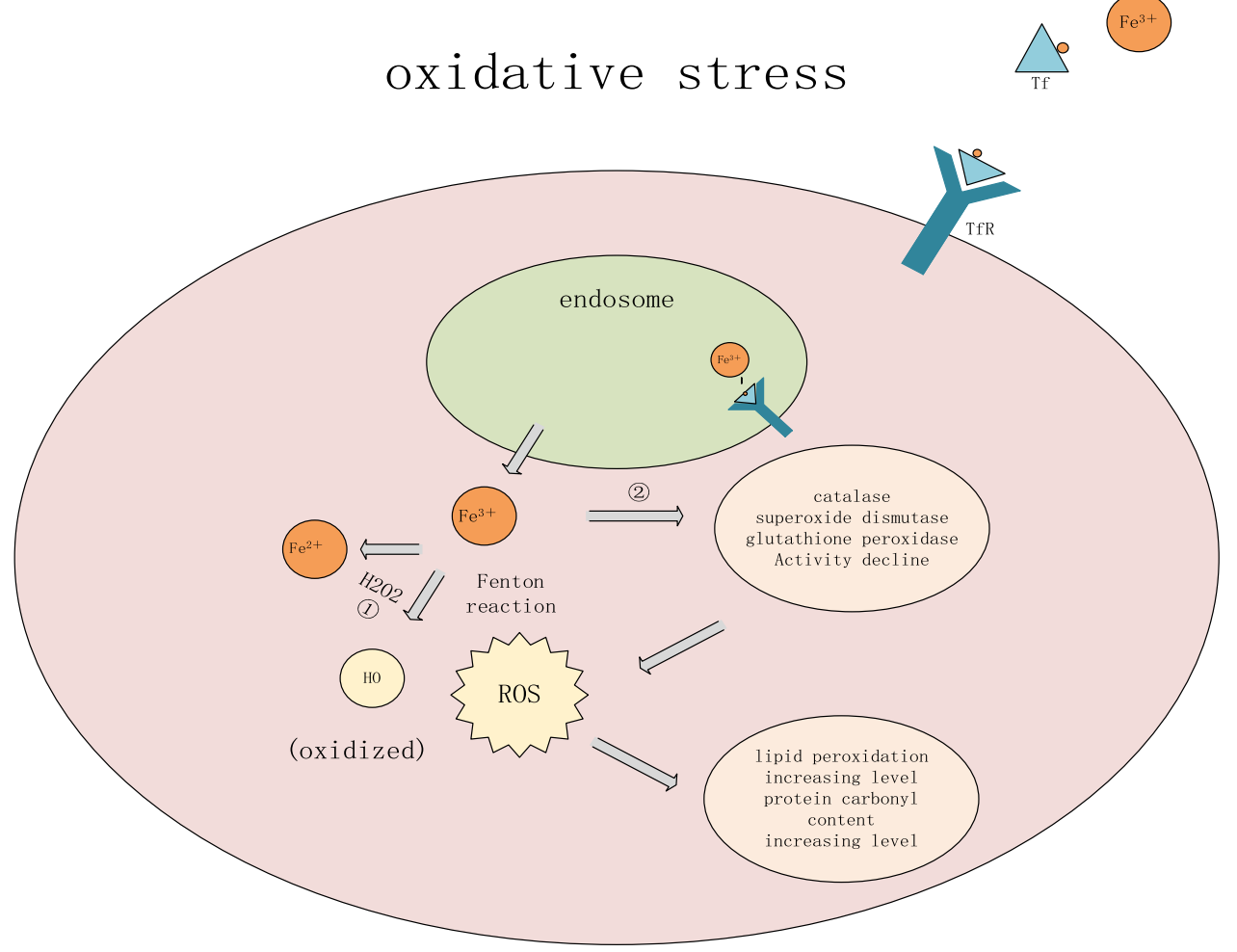

size of the wear particles of biomaterials is also related to the amount of ROS produced. Co nanoparticles (CoNPs) and $\mathrm{Co}$ (II) can significantly reduce cell vitality, while Co (II) has a weak induction effect on cell ROS production [62]. Thus, Nanoparticles (below $100 \mathrm{~nm}$ ) have a greater potential for surface-cell interaction than micron-sized particles, theoretically leading to dose-dependent inflammation [63, 64]. The positive LC3 points, the high expression LC3-II and the ultrastructure of autophagy vesicles were observed by confocal microscopy, Western blotting and transmission electron microscopy, which confirmed the autophagy of Ta-NPs in promoting cell proliferation, this effect is important for cells to overcome adverse conditions and maintain physiological balance. This is limited to Ta-NPs concentrations that occur below the autophagy threshold $(10 \mu \mathrm{g} / \mathrm{ml}$, $20 \mu \mathrm{g} / \mathrm{ml}$ ) [65]. If the concentration of Ta-NPs continues to increase and eventually exceeds the autophagy threshold, cell viability may decline linearly. Studies have shown that Ta-NPs begins to induce a decrease in cell viability at a concentration of $25 \mathrm{~g} / \mathrm{ml}$ [66]. So the increased concentration of metal ions in the body is one of the causes of implant failure, Ta's excellent corrosion resistance can minimize this adverse effect.

\section{Ta has excellent biocompatibility}

\subsection{Cytological experiment}

Methods to evaluate the biocompatibility of different biomaterials in vitro involve the effects of materials on cell growth and proliferation. Cell types commonly used for studying cytotoxicity during in vitro experiments on metal implants include bone marrow mesenchymal stem cells (BMMSCs), osteoblasts, bone cells, fibroblasts, and other normal tissue cells, and leukocytes, etc., which increase quantitatively during inflammation in the body. Figure 4 shows a pattern of adhesion and morphological changes of fibroblasts on the Ta surface. Although Ta is bioinert, it exhibits excellent cellular compatibility. Cell remodeling is a necessary condition for cell adhesion and extracellular matrix formation, cells can express proteins to modify the surface, and cells can also adapt to the attached surface, changes in the cytoskeleton are closely related to cell remodeling, and the two complement each other [67]. The cell volume was increased by $50 \%$ observed by an atomic force microscope (AFM) when the mouse MC3T3E1 pre-osteoblasts were exposed to the Ta substrate [68]. Modin et al. confirmed by cryo-SEM that the average diffusion area of MC3T3-E1 cells on Cr was only two-thirds of that of Ta [69]. Tang et al. observed the morphology and actin skeleton of hBMSCs on the surface of porous Ta coating prepared by vacuum plasma spraying (VPS) 


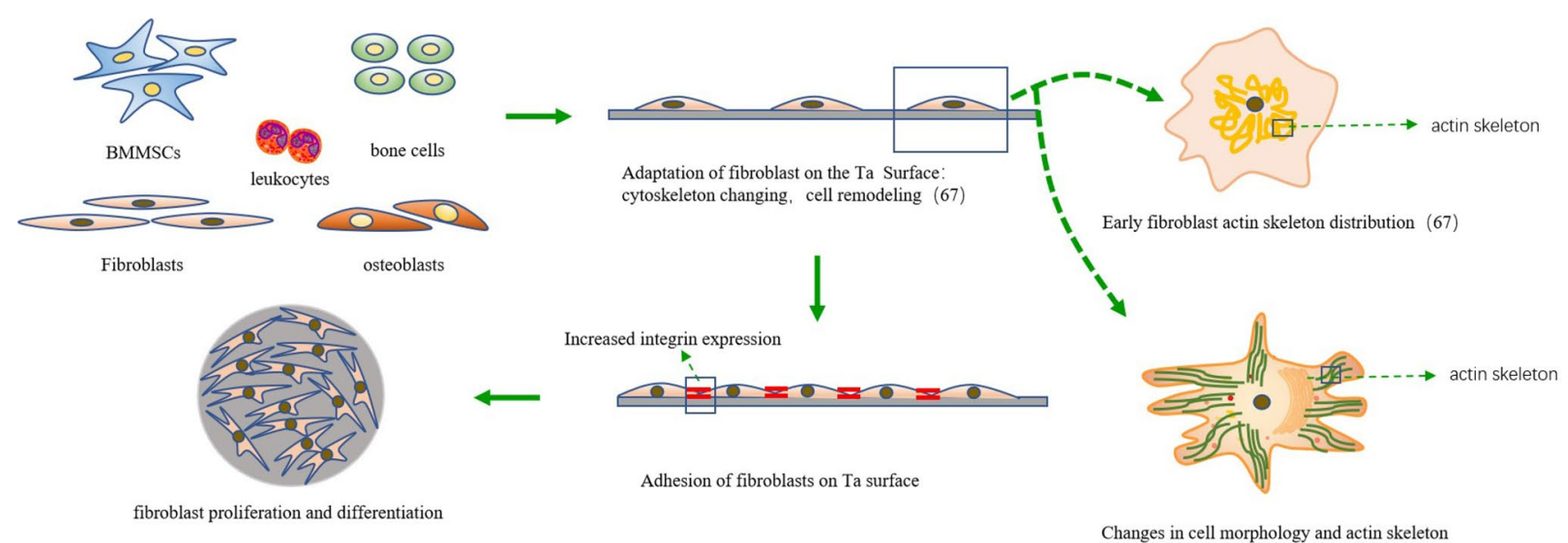

distribution over time (67)

Fig. 4 Take fibroblasts as an example, simulating the morphological changes of cells on Ta surface

under an electron microscope and confocal microscopy, the results showed that the hBMSCs on Ta coating had different cytoskeletal tension and flat expansion shape, while the Ti coating showed contraction shape [70]. Mikhail et al. showed that Ta and Ti coating on Nitinol alloy formed a fused monolayer after 5 days of cell culture, indicating that Ta and Ti coating surface was conducive to cell diffusion [61]. In the early adhesion, the fibroblast actin skeleton was closely wrapped around the nucleus, gradually, the cell morphology changed to polygon, and actin concentrated in the leading edge of the cell over time, and then gradually formed actin fiber [67]. Some scholars have observed by the fluorescence microscope that the $4 \mathrm{~h}$ average area of human mesenchymal stem cells (HMSCs) attached to the Ta surface increased by $33 \%$ and $23 \%$ compared with the surface of $\mathrm{Cr}$ and $\mathrm{Ti}$, respectively, showing a stronger tensile appearance. Compared with $\mathrm{Ta}$, $\mathrm{Ti}$ cell proliferation was significantly increased after 4 days, the average cell area of $\mathrm{Cr}$ decreased and the proliferation ability was poor [71]. This is slightly different from the results of Hofstetter et al.'s in vitro study on the metal coating, which prepared 6 kinds of coatings by plasma vapor deposition (PVD), among them, Ta is more effective than $\mathrm{Ti}$ in cell proliferation, and similarly, $\mathrm{Cr}$ has the lowest surface proliferation [72]. From these results, it can be seen that the biocompatibility of $\mathrm{Cr}$ is poor. The difference between $\mathrm{Ti}$ and Ta may be due to differences in early osteogenic differentiation ability, Ta can promote early bone integration. Cell adhesion and proliferation play a very important role in the whole cycle of cells and subsequently promote the differentiation of cells and the formation of the extracellular matrix.

\subsection{Molecular biology experiment}

In addition to the important role of cell adhesion and proliferation in the initial stage of cell growth, the osseointegration capability of Ta as a bone implant material needs to be evaluated. The morphological expansion, proliferation, and differentiation of cells on the surface of biomaterials are related to the expression of a series of genes and proteins after the cells are stimulated by the surface of the biomaterial. Some studies have shown that Ta has better osteogenic differentiation ability than $\mathrm{Ti}$ in prosthesis and implant coating, and the structural and chemical properties of the material surface have a significant influence on cell behavior, as well as the subsequent bone induction and integration [70-72]. The expression of ALP is a marker of osteoblast differentiation, expression analysis of bonerelated genes is also used to evaluate the osteogenic differentiation ability of cells, for example, type I collagen COL1A 1 is the main component of the extracellular matrix of bone cells, and BGLAP is a marker of late osteoblast differentiation [72]. Runx 2 has been identified as a key transcription factor regulating osteogenesis and a controlling gene in the early stage of osteogenesis differentiation. OPN is an indicator of medium stage differentiation and osteocalcin (OC) is an indicator of late-stage differentiation [73]. Mengmeng et al. studied the effect of intrinsic chemical properties of the Ta and Ti surface (except the effect of surface roughness) on the osteogenic properties of BMSCS. The results showed that mRNA expression levels of integrin a5, integrin $\beta 1$, Runx 2 , and downstream effector factors ALP, OCN and COL-I on the Ta surface were 1.5-2.1 times higher than those on Ti surface [74]. Integrin plays an important role in the formation of focal adhesion complex, mediating intracellular signal transduction and regulating cell differentiation [74]. The osteogenic effect of 
cells on the Ta surface is better than that on Ti surface cells, which may be due to the stronger ability of the surface to trigger integrin.

\subsection{Protein adsorption experiment}

Metal implants exposed to complex physiological conditions come into contact with a variety of high molecular weight organic compounds, especially proteins. When a protein-containing liquid touches a foreign body, it immediately coats the surface with an adsorbed protein. There is no effective way to elucidate the effect of the adsorption of this protein on the metal implant, which may be related to the type and concentration of the protein and the nature of the implant material [75]. On the one hand, protein adsorption is an important step for early cell adhesion and diffusion, which is closely related to the life of the implanted device. As a thin film on the metal surface, it also protects the passive film from wear and corrosion on many repaired artificial joints. On the other hand, the metal ions are combined with the protein to form a colloidal metal-organic compound, and the migration of the complex from the interface increases the dissolution rate. Besides, it may be related to thrombosis and foreign body reaction $[75,76]$. Therefore, the effect of protein adsorption on metal implants depends on the specific related environment. Proteins commonly used as indicators of cellular biocompatibility include extracellular protein bovine serum albumin (BSA), fibrinogen, lysozyme (LYS), collagen, etc. Figure 5 shows the adsorption of different types of proteins on the Ta surface. Currently, due to Ta's high density and other characteristics, it is not suitable for largescale implantation. Therefore, Ta coating and $\mathrm{Ta}_{2} \mathrm{O}_{5}$ thin film are the main forms of research on Ta in vitro. For Ta, topographic surface design, especially nanoscale chemistry and morphology, is conducive to protein adsorption, which will promote cell proliferation and differentiation, especially the enhancement of bone regeneration ability $[77,78]$. Quartz crystal microbalance (QCM-D) is a unique technique to measure the adsorption capacity and viscoelasticity of proteins on the metal surface, which can be used to infer the orientation and conformation changes of adsorbed proteins $[79,80]$. Rechendorff et al. studied the changes of proteins adsorbed on Ta films with different roughness by using QCM-D, the results showed that the adsorption amount of fibrinogen increased with the increase of surface roughness, because it had a slender shape and could be adsorbed and bound together in
Fig. 5 The adsorption of different types of proteins on the Ta surface

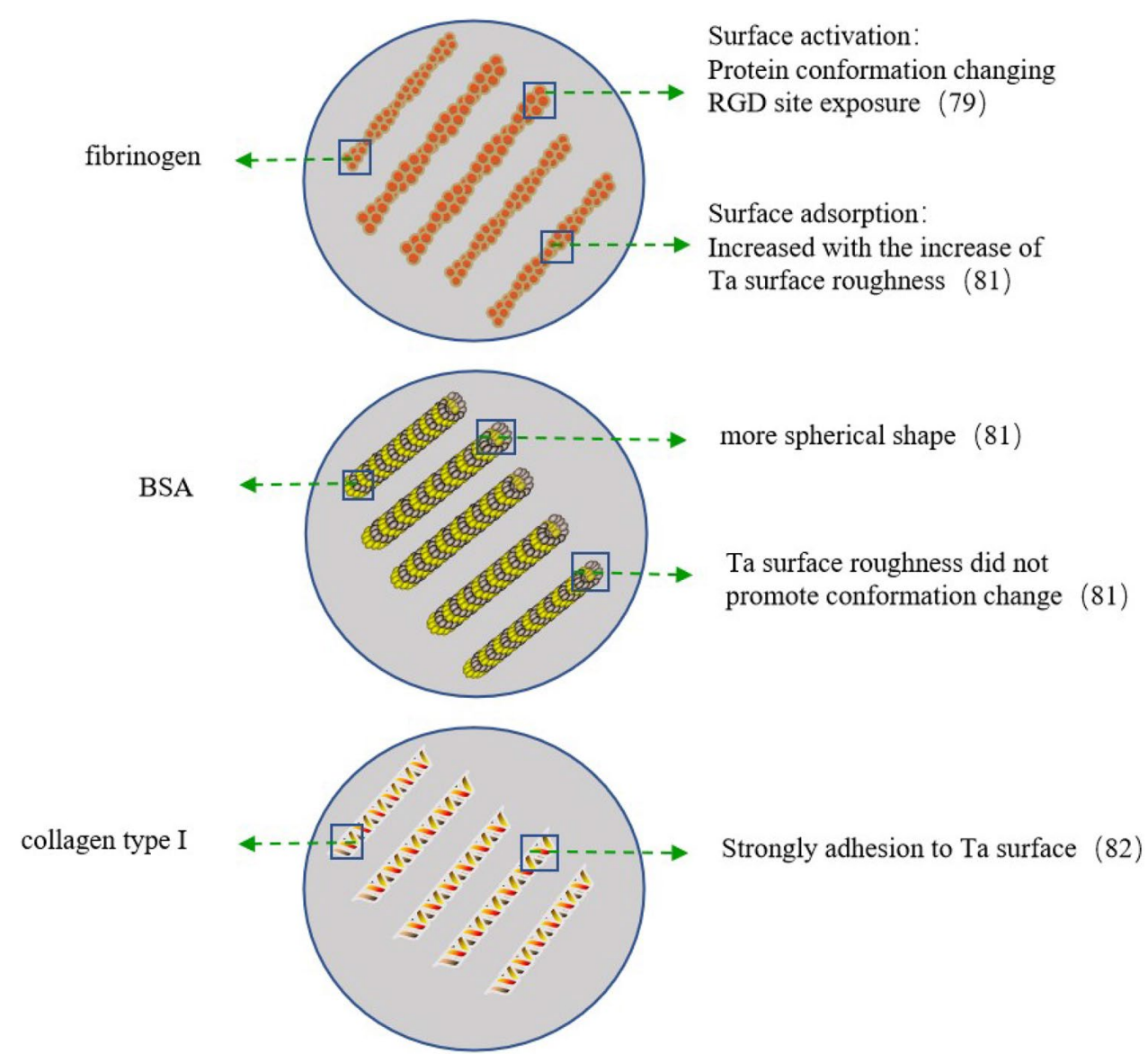


different directions with the growth of strong anisotropy, while BSA had a more spherical shape, and roughness did not promote conformation change [81]. Hovgaard et al. also believe that nano Ta oxide promotes additional protein conformational changes and subsequent RGD site exposure, thereby activating the surface [79]. Studies have shown that type I collagen is also widely used in the adhesion model system of various cell lines in vitro, it has strong adhesion to Ta, which may be because the longitudinal period of collagen fiber matches the grain size of Ta's structural domain and also leads to stronger hydrophobic properties on the surface [82]. Among different Ta Nanomorphology, the regions with the highest amount of fibronectin adhesion have more effective utilization of cell binding areas, and the formation of fibronectin adhesion spots is also the most obvious [83]. Also, physical adsorption and silylation covalently combined methods were used to fix polypeptides onto Ta-based materials, and functional modification of the Ta surface was carried out to improve biological activity [84]. Sharma et al. observed with 251 labeled protein that when the thickness of the Ta oxide film increased, the water contact angle decreased, and the adsorption of fibrin on the oxide film coating increased compared with naked Ta [85]. Lundin et al. showed that although almost all proteins had a high affinity for Cr and SS (AISI 316) under acidic and neutral conditions, increasing the release of ions of $\mathrm{Cr}$ and SS, which may be due to the complexation between proteins and metals [86]. Protein adsorption determines subsequent cell-surface interactions. Among them, the adsorption of albumin as a cell adhesion inhibitor does not contain the peptide sequence that promotes the adhesion of specific cells. However, cells growing on the surface of Ta covered with fibronectin and serum proteins can reconstruct the surface to meet the requirements of cell growth through the production of endogenous matrix proteins [67].

\subsection{Hematology experiment}

Any biological material in contact with blood needs to be evaluated for blood compatibility. The effects of biomaterials on erythrocyte morphology and thrombosis were evaluated by platelet adhesion and activation, hemolysis test and clotting time test $[87,88]$. Platelet works in the case of vascular injury, platelet diffusion and aggregation on the surface are a sign of platelet activation and are considered to be the main mechanism of thrombosis, which is adverse to blood compatibility of metal implant materials [88]. And in the hemolysis test, hemolysis rate measurement is important, besides, the morphology of red blood cells on the surface of the material can be observed by scanning electron microscope and optical microscope. The morphology of red blood cells on the surface of materials with a low hemolysis rate is often a normal double concave. If there is deformation and swelling, the hemolysis rate will increase to a certain extent [88]. Under normal circumstances, the hemolysis rate below the security threat threshold of $5 \%$ is considered qualified [89]. These indexes related to blood compatibility are closely related to surface energy, interfacial tension, grain size and other surface physical properties of Ta [90]. Adding Ta to different metal surface membranes in vitro can enhance the blood compatibility of metals. Ti oxide films containing $\mathrm{Ta}$ $\left(\mathrm{Ti}\left(\mathrm{Ta}^{+5}\right) \mathrm{O}_{2}\right)$ have been prepared by magnetron sputtering and thermal oxidation, indicating excellent biocompatibility, this is partly because the smaller surface force $y$ s on the surface membrane and the smaller boundary membrane surface tension $\gamma c$ blood cause less distortion and adsorption of proteins on the surface, mainly fibrinogen, which is closely related to platelet activation [91]. Another study has shown that Ta injection technology was used to prepare $\mathrm{TiO}_{2} / \mathrm{Ta}_{2} \mathrm{O}_{5}$ composite nanofilm on the surface of $\mathrm{NiTi}$ shape memory alloy, after implantation, surface energy and interfacial tension were decreased, Water Contact Angle was increased, platelet adhesion and activation were weakened, hemolysis rate was reduced by at least $46 \%$, and corrosion resistance was improved [90]. Nie et al. used equal channel angular pressing (ECAP) technology to prepare 8-pass block superfine crystal pure Ta, with more passes and more refined grains, the average grain size of the eighth pass reached $220 \mathrm{~nm}$, and it was a typical body-centered cubic (BCC) structure. With the decrease of particle size, hemolysis rate and the number of adhered platelets decreased, mechanical strength increased [87]. Studies on other metals have shown that the most important factor for thrombotic reduction is the minimal adsorption of thrombotic blood proteins on the surface, thereby reducing the interaction with coagulation factors. Although the adsorption of fibronectin on the surface of Ta will further promote the early diffusion and adhesion of cells, it may also activate the coagulation cascade reaction and promote the adhesion and aggregation of platelets. In the complex physiological environment of the body, this mechanism of platelet activation is inevitable after biomaterials are implanted into the bone. Therefore, it is necessary to evaluate and consider the ways to enhance the ability of bone binding and integration of adherent cells on the surface of materials and to minimize platelet adhesion and activation.

\subsection{Porous tantalum trabecular metal}

Biomedical applications of solid Ta have been limited due to its high mechanical strength and density $(16.68 \mathrm{~g} /$ $\mathrm{cm}^{3}$ ), PTTM is mainly used in bone tissue implantation at present. PTTM has a connected porous structure with a 
pore size of $300-600 \mu \mathrm{m}$ and a porosity of $75-85 \%$ [92]. The main preparation methods include chemical vaporous deposition (CVD), organic foam impregnation and laser engineering net forming [93-95]. Porous Ta with different pore diameters and porosity can be produced by different manufacturing methods. The pore diameter is closely related to the growth of tissue cells and blood vessels, thus the porosity is designed to coordinate the elastic modulus between Ta and bone tissue. Bone induction (inducing osteogenic differentiation of MSCs) is also a necessary condition for porous Ta to induce bone formation and enhance bone bonding. With the increase of bone incorporation, the average interfacial shear strength is higher than that of other porous materials with lower volume porosity [96]. This special geometric structure and strength are of great significance to the biological properties of implanted materials.

PTTM has long been used in orthopedics to promote neovascularization, wound healing and osteogenesis, and in recent years, it has been incorporated into Ti alloy dental implants [97-99]. In vivo experiments, studies have shown that the bone growth, the amount of new mineralized bone and the rate of new bone formation of Ta trabecular dental implant (TM) is better than that of $\mathrm{Ti}$ dental implant (TSV), and TM dental implant has considerable implant stability and bone-implant contact [100, 101]. At present, many studies have incorporated TM into Ti alloy dental implants to improve osseointegration, and the results show that there is less bone loss around TM implants than the Ti group [99]. Macheras et al. analyzed the survival rate of the porous Ta acetabular component in primary total hip arthroplasty (THA) and followed up for an average of 18 years. Harris hip score, Oxford hip score, and range of motion were significantly improved in all cases $(P<0.001)$. At the last follow-up, all acetabular cups showed excellent clinical and imaging results [102]. Sagherian et al. retrospectively analyzed patients who failed ankle arthroplasty with TM treatment, followed up for an average of 57 months, and the American Orthopedic Foot and Ankle Score (AOFAS) increased from 30.7 preoperatively (range 20-39) to 72.7 (range 65-77), with an average of 3 months after arthrodesis without complications [103]. Papacci et al. concluded that anterior cervical discectomy and fusion (ACDF) with a porous Ta cage is a safe approach with long-term clinical benefits and a very low incidence of complications [104]. It can be seen that the joint reconstruction and revision of TM can be said to be successful in clinical application, which greatly improves the quality of life of patients. However, in the case of failure of porous Ta implant, the space between bone and implant can be seen, with sparse and isolated bone growth, which may be due to incorrect position, ineffective bone implantation, ineffective core decompression, etc. [105]. The initial stability of porous Ta implants should not only have good bone integration but also related to reasonable implant diameter and bone mineral density. In dense bone masses, large-diameter implants provide a larger bone-implant contact area, which is more stable than narrow implants, however, in cartilage masses, conical screw implants are more stable than TM implants because of the existence of threads on its entire surface [106]. Therefore, the success of the implant depends not only on the inherent properties of the material but also on the corresponding mechanical properties of the corresponding part.

\section{Conclusion}

At present, the main research direction of Ta-based biomaterials in the medical field is as bone implant materials. The evaluation of biocompatibility of Ta-based biomaterials mainly focuses on corrosion resistance, cell growth, and bone integration. When electrochemical corrosion behavior characterizes the corrosion resistance of $\mathrm{Ta}$, the formation and stability of surface passivation film play an important role in the measurement results. Therefore, the stable surface oxidation film of Ta is one of the key factors of corrosion resistance. Compared with other metal materials, Ta as an implant material has the following advantages: (1) PTTM has an elastic modulus that matches human bone tissue, which can well meet the requirements of bone tissue replacement materials. (2) Ta's excellent corrosion resistance can greatly reduce the release of metal ions caused by corrosion of implants in vivo. (3) The surface cell behavior of $\mathrm{Ta}$ is better than that of $\mathrm{Cr}, \mathrm{Ni}$, and even Ti. (4) Most kinds of literature reported that Ta had better osteogenic differentiation ability than $\mathrm{Ti}$ in prosthesis and implant coating, which could promote early osseointegration and stability of implants. (5) The nano-scale chemistry and morphology of the Ta topographic surface is beneficial to protein adsorption and the improvement of blood compatibility. (6) Regular follow-up after intraosseous PTTM implantation revealed excellent clinical effects, quality of life and a low incidence of complications. Although Ta has many advantages, Ta is a refractory metal element with a high melting point, easy oxidation under high temperature, and other characteristics, difficult material processing and high cost, which limit its wide application. In the early stage, we combined 3D printing technology to break the bottleneck of processing technology. In a word, Ta has a wide range of medical prospects because of its many characteristics make it suitable for in vivo implantation.

Acknowledgements The authors acknowledge Professor Libin Liu for his help with the systematic review.

\section{SN Applied Sciences


Author's contribution All authors contributed to this article's conception and design. The following is the specific division for each person, the theme was presented by $\mathrm{JH}$ and ZY; the first draft of the manuscript was written by $\mathrm{HL}$; relevant documents were collected by $J Z$ and $X C ; L L, G L$, and JL assisted in references and figures; the grammatical errors were corrected by LC.

Funding This work was supported by the fund of Hunan 2017 Key R \& D Project of China (2017GK2265), Hunan 2018 Key R \& D Project of China (2018SK2104), and Hunan department of health project of China (B2015-142).

\section{Compliance with ethical standards}

Conflict of interest The author(s) declared no potential conflicts of interest with respect to authorship, and/or publication of this review.

\section{References}

1. Guo N (2012) Tantalum industry development analysis. China Met Bull 12:38-40

2. Hu ZW, Li ZK, Zhang TJ (2003) New development and application of tantalum and tantalum alloy. Rare Met Cement Carbides 31:34-36

3. Strecker E-P, Boos I, Schmid G, Göttmann D, Vetter S (2000) Flexible tantalum stents for the treatment of renovascular hypertension: a 10-year experience. Eur Radiol 10:1144-1151

4. Liu ZH, Guo WS, Li ZR, Cheng LM, Zhang QD, Yue DB, Shi ZC, Wang BL, Sun W, Zhang NF (2014) Porous tantalum rods for treating osteonecrosis of the femoral head. Genet Mol Res 13:8342-8352

5. Lee GW, Park KS, Kim DY, Lee YM, Eshnazarov KE, Yoon TR (2016) Results of total hip arthroplasty after core decompression with tantalum rod for osteonecrosis of the femoral head. Clin Orthop Surg 8:38-44

6. Sagherian BH, Claridge RJ (2015) Salvage of failed total ankle replacement using tantalum trabecular metal: case series. Foot Ankle Int 36:318-324

7. King V, Swart A, Winder MJ (2016) Tantalum trabecular metal implants in anterior cervical corpectomy and fusion: 2-year prospective analysis. J Clin Neurosci 32:91-94

8. Konan S, Duncan CP, Masri BA, Garbuz DS (2016) Porous tantalum uncemented acetabular components in revision total hip arthroplasty: a minimum ten-year clinical, radiological and quality of life outcome study. Bone Joint J 98:767-771

9. Zou X, Li H, Bünger M, Egund N, Lind M, Bünger C (2004) Bone ingrowth characteristics of porous tantalum and carbon fiber interbody devices: an experimental study in pigs. Spine J 4:99-105

10. Zhang Y, Ahn PB, Fitzpatrick DC, Anneliese DH, Poggie RA, Brown TD (1999) Interfacial frictional behavior: cancellous bone, cortical bone, and a novel porous tantalum biomaterial. J Musculoskeletal Res 3:245-251

11. Sevilla P, Aparicio C, Planell JA et al (2007) Comparison of the mechanical properties between tantalum and nickel-titanium foams implant materials for bone ingrowth applications. J Alloys Compd 39:67-73

12. Levine BR, Sporer S, Poggie RA, Della Valle CJ, Jacobs JJ (2006) Experimental and clinical performance of porous tantalum in orthopedic surgery. Biomaterials 27:4671-4681
13. Heiner AD, Brown TD, Poggie RA (2001) Structural efficacy of a novel porous tantalum implant for osteonecrosis grafting. Trans Orthop Res Soc 26:480

14. Frigg A, Dougall H, Boyd S, Nigg B (2010) Can porous tantalum be used to achieve ankle and subtalar arthrodesis. Clin Orthop Relat Res 468:209-216

15. Liu J, Zhou X, Wang H, Yang H, Ruan J (2019) In vitro cell response and in vivo primary osteointegration of highly porous $\mathrm{Ta}-\mathrm{Nb}$ alloys as implant materials. J Biomed Mater Res B Appl Biomater 107:573-581

16. Wang JX, Liao SH, Zhu XH, Wang Y, Ling CX, Ding X, Fang YM, Zhang XH (2011) Real time E-3D simulation for nose surgery and automatic individual prosthesis design. Comput Methods Progr Biomed 104:472-479

17. Huang JH, Liu G, Yao ZG, Zhou HB, Huang YL, Zuo J, Li K, Yan CY (2015) Development and application of 3D manufacturing in biomedical materials. Chin J Stomatol 3:43-46

18. Hee AC, Cao HI, Zhao Y, Jamali SS, Bendavid A, Martin PJ (2018) Cytocompatible tantalum films on Ti6AI4V substrate by filtered cathodic vacuum arc deposition. Bioelectrochemistry 122:32-39

19. Li HZ, Zhao X, Xu J (2015) MRI-compatible Nb-60Ta-2Zr alloy for vascular stents: electrochemical corrosion behavior in simulated plasma solution. Mater Sci Eng C Mater Biol Appl 56:205-214

20. Prando D, Brenna A, Bolzoni FM, Diamanti MV, Pedeferri M, Ormellese M (2017) Electrochemical anodizing treatment to enhance localized corrosion resistance of pure titanium. J Appl Biomater Funct Mater 15:e19-e24

21. Liu Z, Thompson GE (2015) Formation of porous anodic oxide film on titanium in phosphoric acid electrolyte. JMEPEG 24:59-66

22. Houb-Dine A, Bahije L, Zaoui F (2018) Fluoride induced corrosion affecting titanium brackets: a systematic review. Int Orthod 16:1-10

23. Lindholm-Sethson B, Ardlin BI (2007) Effects of $\mathrm{pH}$ and fluoride concentration on the corrosion of titanium. J Biomed Mater Res A 86:149-159

24. Bilhan H, Bilgin T, Cakir AF, Yuksel B, Von Fraunhofer JA (2007) The effect of mucine, $\lg A$, urea, and lysozyme on the corrosion behavior of various non-precious dental alloys and pure titanium in artificial saliva. J Biomater Appl 22:197-221

25. Reclaru L, Eschler PY, Lerf R, Blatter A (2005) Electrochemical corrosion and metal ion release from $\mathrm{Co}-\mathrm{Cr}-\mathrm{Mo}$ prosthesis with titanium plasma spraycoating. Biomaterials 26:4747-4756

26. Souza JC, Barbosa SL, Ariza EA, Henriques M, Teughels W, Ponthiaux P, Celis JP, Rocha LA (2015) How do titanium and Ti6AI4V corrode in ffluoridated medium as found in the oral cavity? An in vitro study. Mater Sci Eng C Mater Biol Appl 47:384-393

27. Herting G, Wallinder IO, Leygraf C (2008) Metal release rate from AISI 316L stainless steel and pure $\mathrm{Fe}, \mathrm{Cr}$ and $\mathrm{Ni}$ into a synthetic biological medium - a comparison. J Environ Monit 10:1092-1098

28. Mun AG, Benitez G, Vela ME, Salvarezza RC (2004) Influence of the adsorption of $\mathrm{N}$ species on the anodic dissolution of $\mathrm{Ni}$. Langmuir 20:2361-2368

29. Xu WC, Yu F, Yang LH, Zhang B, Hou B, Li Y (2018) Accelerated corrosion of $316 \mathrm{~L}$ stainless steel in simulated body fluids in the presence of $\mathrm{H}_{2} \mathrm{O}_{2}$ and albumin. Mater Sci Eng C Mater Biol Appl 92:11-19

30. Milosev I, Strehblow HH (2000) The behavior of stainless steels in physiological solution containing complexing agent studied by X-ray photoelectron spectroscopy. J Biomed Mater Res $52: 404-412$ 
31. Wang Z, Zhang L, Zhang ZR et al (2018) Combined effect of pH and $\mathrm{H}_{2} \mathrm{~S}$ on the structure of passive film formed on type $316 \mathrm{~L}$ stainless steel. Appl Surf Sci 458:686-699

32. Hedberg Y, Odnevall Wallinder I (2014) Metal release and speciation of released chromium from a biomedical CoCrMo alloy into simulated physiologically relevant solutions. J Biomed Mater Res Part B 102B:693-699

33. Pound BG (2010) Electrochemical behavior of cobalt-chromium alloys in a simulated physiological solution. J Biomed Mater Res 94:93-102

34. Li YS, Wang K, He P, Huang BX et al (1999) Surface-enhanced Raman spectroelectrochemical studies of corrosion fifilms on implant CoCr alloy in biosimulating solution. J Raman Spectrosc 30:97-103

35. Diaz I, Martinez-Lerma JF, Montoya R, Llorente I, Escudero ML, García-Alonso MC (2017) Study of overall and local electrochemical responses of oxide films grown on $\mathrm{CoCr}$ alloy under biological environments. Bioelectrochemistry 115:1-10

36. Tsuchiya T, Imai H, Miyoshi S, Glans PA, Guo J, Yamaguchi S (2011) X-Ray absorption, photoemission spectroscopy, and Raman scattering analysis of amorphous tantalum oxide with a large extent of oxygen nonstoichiometry. Phys Chem Chem Phys 13:17013-17018

37. Pérez-Walton S, Valencia-Balvín C, Padilha AC, Dalpian GM, Osorio-Guillén JM (2016) A search for the ground state structure and the phase stability of tantalum pentoxide. J Phys Condens Matter 28:035801

38. Mei SQ, Yang LL, Pan Y, Wang D, Wang X, Tang T, Wei J (2018) Influences of tantalum pentoxide and surface coarsening on surface roughness, hydrophilicity, surface energy, protein adsorption and cell responses to PEEK based biocomposite. Colloids Surf B Biointerfaces 174:207-215

39. Wang N, Li H, Wang J, Chen S, Ma Y, Zhang Z (2012) Study on the anticorrosion, biocompatibility, and osteoinductivity of tantalum decorated with tantalum oxide nanotube array films. ACS Appl Mater Interfaces 4:4516-4523

40. Zitter H, Plenk H Jr (1987) The electrochemical behavior of metallic implant materials as an indicator of their biocompatibilit. J Biomed Mater Res 21:881-896

41. Kim H, Johnson JW (1999) Corrosion of stainless steel, nickeltitanium, coated nickel-titanium, and titanium orthodontic wires. Angle Orthodontis 69:39-44

42. Bermúdez MD, Carrión FJ, Martínez-Nicolás G, López R (2005) Erosion-corrosion of stainless steels, titanium, tantalum and zirconium. Wear 258:693-700

43. Liu LL, Xu J, Jiang SY (2016) Nanocrystalline $\beta$-Ta coating enhances the longevity and bioactivity of medical titanium alloys. Metals 6:221

44. Myers S, Lin JL, Souza RM, Sproul WD, Moore JJ (2013) The $\beta$ to a phase transition of tantalum coatings deposited by modulated pulsed power magnetron sputtering. Surf Coat Technol 214:38-45

45. Navid AA, Hodge AM (2012) Nanostructured alpha and beta tantalum formation - relationship between plasma parameters and microstructure. Mater Sci Eng A 536:49-56

46. Lee SH, Kim BO, Seo JH (2015) The electrochemical behavior of Mo-Ta alloy in phosphoric acid solution for TFT-LCD application. J Nanosci Nanotechnol 10:7770-7776

47. Ferko MA, Catelas I (2018) Effects of metal ions on caspase-1 activation and interleukin- $1 \beta$ release in murine bone marrowderived macrophages. PLoS ONE 13(8):1-18

48. Lawrence H, Mawdesley AE, Holland JP, Kirby JA, Deehan DJ, Tyson-Capper AJ (2016) Targeting toll-like receptor 4 prevents cobalt-mediated inflammation. Oncotarget 7:7578-7585
49. Bechara R, Antonios D, Azouri H, Pallardy M (2017) Nickel sulfate promotes IL-17A producing CD4 + T cells by an IL-23-dependent mechanism regulated by TLR4 and Jak-STAT pathways. J Invest Dermatol 137:2140-2148

50. Martinez-Finley EJ, Chakraborty S, Fretham SJ, Aschner M (2012) Cellular transport and homeostasis of essential and nonessential metals. Metallomics 4:593-605

51. El Hage Chahine JM, Hémadi M, Ha-Duong NT (2012) Uptake and release of metal ions by transferrin and interaction with receptor 1. Biochim Biophys Acta 1820:334-347

52. Beyersmann D, Hartwig A (2008) Carcinogenic metal compounds: recent insight into molecular and cellular mechanisms. Arch Toxicol 82:493-512

53. Taju G, Abdul Majeed S, Nambi KSN, Sahul Hameed AS (2017) Application of fish cell lines for evaluating the chromium induced cytotoxicity, genotoxicity and oxidative stress. Chemosphere 184:1-12

54. Salloum Z, Lehoux EA, Harper ME, Catelas I (2018) Effects of cobalt and chromium ions on oxidative stress and energy metabolism in macrophages in vitro. J Orthop Res 36:1-35

55. Hagmann S, Kirsch J, Kretzer JP, Moradi B (2013) In vitro analysis of the impact of metal ions on human lymphocyte cultures. Orthopade 42:643-650

56. Indra R, Purna Sai K, Rajaram A, Rajaram R (2015) Effect of Cr(VI) and $\mathrm{Ni}(\mathrm{II})$ metal ions on human adipose derived stem cells. Biometals 28:21-33

57. Xu J, Yang J, Nyga A, Ehteramyan M, Moraga A, Wu Y, Zeng L, Knight MM, Shelton JC (2018) Cobalt(II) ions and nanoparticles induce macrophage retention by ROS-mediated down-regulation of RhoA expression. Acta Biomater 72:434-446

58. Oskouei RH, Barati MR, Farhoudi H, Taylor M, Solomon LB (2017) A new finding on the in vivo crevice corrosion damage in a CoCrMo hip implant. Mater Sci Eng C 79:390-398

59. Molders M, Felix J, Bingmann D, Hirner A, Wiemann M (2007) Uptake of nickel from $316 \mathrm{~L}$ stainless steel into contacting osteoblastic cells and metal ion interference with BMP-2-induced alkaline phosphatase. J Biomed Mater Res A 83:303-312

60. Sevostyanov MA, Nasakina EO, Baikin AS, Sergienko KV, Konushkin SV, Kaplan MA et al (2018) Biocompatibility of new materials based on nano-structured nitinol with titanium and tantalum composite surface layers: experimental analysis in vitro and in vivo. J Mater Sci Mater Med 29:33

61. Qiao Y, Ma L (2013) Quantification of metal ion induced DNA damage with single cell array based assay. Analyst 139:5713-5718

62. Liu Y, Hong H, Lu X, Wang W, Liu F, Yang H (2017) L-ascorbic acid protected against extrinsic and intrinsic apoptosis induced by cobalt nanoparticles through ROS attenuation. Biol Trace Elem Res 175:428-439

63. Au A, Ha J, Hernandez M, Polotsky A, Hungerford DS, Frondoza CG (2006) Nickel and vanadium metal ions induce apoptosis of T-lymphocyte Jurkat cells. J Biomed Mater Res A 79:512-521

64. Madl AK, Liong $M$, Kovochich $M$, Finley BL, Paustenbach DJ, Oberdörster G (2015) Toxicology of wear particles of cobaltchromium alloy metal-on-metal hip implants part I: physicochemical properties in patient and simulator studies. Nanomedicine 11:1201-1215

65. Kang C, Wei L, Song B, Chen L, Liu J, Deng B, Pan X, Shao L (2017) Involvement of autophagy in tantalum nanoparticleinduced osteoblast proliferation. Int J Nanomed 12:4323-4333

66. Wang P, Qiao P, Xing H, Zhang R, Lingling E, Liu H (2020) Cytotoxicity, oxidative stress, and autophagy effects of tantalum nanoparticles on MC3T3-E1 mouse osteoblasts. J Nanosci Nanotechnol 20:1417-1424 
67. Lord MS, Modin C, Foss M, Duch M, Simmons A, Pedersen FS, Besenbacher F, Milthorpe BK (2008) Extracellular matrix remodelling during cell adhesion monitored by the quartz crystal microbalance. Biomaterials 29:2581-2587

68. Andersen LK, Contera SA, Justesen J, Duch M, Hansen O, Chevallier J, Foss M, Pedersen FS, Besenbacher F (2005) Cell volume increase in murine MC3T3-E1 pre-osteoblasts attaching onto biocompatible tantalum observed by magnetic $A C$ mode atomic force microscopy. Eur Cells Mater 10:61-68

69. Modin C, Stranne AL, Foss M, Duch M, Justesen J, Chevallier J, Andersen LK, Hemmersam AG, Pedersen FS, Besenbacher F (2006) QCM-D studies of attachment and differential spreading of pre-osteoblastic cells on $\mathrm{Ta}$ and $\mathrm{Cr}$ surfaces. Biomaterials 27:1346-1354

70. Tang Z, Xie Y, Yang F, Huang Y, Wang C, Dai K, Zheng X, Zhang X (2013) Porous tantalum coatings prepared by vacuum plasma spraying enhance BMSCs osteogenic differentiation and bone regeneration in vitro and in vivo. PLoS ONE 8:e66263

71. Stiehler $M$, Lind $M$, Mygind T, Baatrup A, Dolatshahi-Pirouz A, Li H, Foss M, Besenbacher F, Kassem M, Bünger C (2008) Morphology, proliferation, and osteogenic differentiation of mesenchymal stem cells cultured on titanium, tantalum, and chromium surfaces. J Biomed Mater Res 86A:448-458

72. Hofstetter W, Sehr H, de Wild M, Portenier J, Gobrecht J, Hunziker EB (2013) Modulation of human osteoblasts by metal surface chemistry. J Biomed Mater Res Part A 101A:2355-2364

73. Ding D, Xie Y, Li K, Huang L, Zheng X (2018) Micro/nano structural tantalum coating for enhanced osteogenic differentiation of human bone marrow stem cells. Materials (Basel) 11:546

74. Lu M, Zhuang X, Tang K, Wu P, Guo X, Yin L, Cao H, Zou D (2018) Intrinsic surface effects of tantalum and titanium on integrin a5 $\beta 1 /$ ERK $11 / 2$ pathway-mediated osteogenic differentiation in rat bone mesenchymal stromal cells. Cell Physiol Biochem 51:589-609

75. Talha $M$, Ma Y, Kumar P, Lin Y, Singh A (2019) Role of protein adsorption in the bio corrosion of metallic implants-a review. Colloids Surf B 176:494-506

76. Hedberg Y, Wang X, Hedberg J, Lundin M, Blomberg E, Wallinder IO (2013) Surface-protein interactions on different stainless steel grades: effects of protein adsorption, surface changes and metal release. J Mater Sci Mater Med 24:1015-1033

77. An R, Fan PP, Zhou MJ, Wang Y, Goel S, Zhou XF, Li W, Wang JT (2019) Nanolamellar tantalum interfaces in the osteoblast adhesion. Langmuir 35:2480-2489

78. Biao MN, Chen YM, Xiong SB, Wu BY, Yang BC (2017) Synergistic effects of fibronectin and bone morphogenetic protein on the bioactivity of titanium metal. J Biomed Mater Res A 105:2485-2498

79. Hovgaard MB, Rechendorff K, Chevallier J, Foss M, Besenbacher $F$ (2008) Fibronectin adsorption on tantalum: the influence of nanoroughness. J Phys Chem B 112:8241-8249

80. Hemmersam AG, Rechendorff K, Foss M, Sutherland DS, Besenbacher F (2008) Fibronectin adsorption on gold, Ti-, and Taoxide investigated by QCM-D and RSA modelling. J Colloid Interface Sci 320:110-116

81. Rechendorff K, Hovgaard MB, Foss M, Zhdanov VP, Besenbacher $F$ (2006) Enhancement of protein adsorption induced by surface roughness. Langmuir 22:10885-10888

82. Li Y, Zhang S, Guo L, Dong M, Liu B, Mamdouh W (2012) Collagen coated tantalum substrate for cell proliferation. Colloids Surf B Biointerfaces 95:10-15

83. Dolatshahi-Pirouz $A$, Jensen $T$, Kraft DC, Foss $M$, Kingshott P, Hansen JL, Larsen AN, Chevallier J, Besenbacher F (2010)
Fibronectin adsorption, cell adhesion, and proliferation on nanostructured tantalum surfaces. ACS Nano 4:2874-2882

84. Mas-Moruno C, Garrido B, Rodriguez D, Ruperez E, Gil FJ (2015) Biofunctionalization strategies on tantalum-based materials for osseointegrative applications. J Mater Sci Mater Med 26:109

85. Sharma CP, Paul W (1992) Protein interaction with tantalum: changes with oxide layer and hydroxyapatite at the interface. J Biomed Mater Res 26:1179-1184

86. Lundin $M$, Hedberg $Y$, Jiang $T$, Herting $G$, Wang $X$, Thormann E, Blomberg E, Wallinder IO (2012) Adsorption and proteininduced metal release from chromium metal and stainless steel. J Colloid Interface Sci 366:155-164

87. Nie FL, Zheng YF, Wang Y, Wang JT (2014) Microstructures, mechanical behavior, cellular response, and hemocompatibility of bulk ultrafine-grained pure tantalum. J Biomed Mater Res B Appl Biomater 102:221-230

88. Wang X, Miao J, Zhao H, Mao C, Chen X, Shen J (2014) Fabrication of nonbiofouling metal stent and in vitro studies on its hemocompatibility. J Biomater Appl 29:14-25

89. ISO 10993-4 (2002) Biological evaluation of medical devices. Part 4: selection of tests for interactions with blood. International Organization for Standardization, Geneva

90. Zhao T, Li Y, Gao Y, Xiang Y, Chen H, Zhang T (2011) Hemocompatibility investigation of the NiTi alloy implanted with tantalum. J Mater Sci Mater Med 22:2311-2318

91. Chen JY, Leng YX, Tian XB, Wang LP, Huang N, Chu PK, Yang $P$ (2002) Antithrombogenic investigation of surface energy and optical bandgap and hemocompatibility mechanism of $\mathrm{Ti}(\mathrm{Ta}(+5)) \mathrm{O} 2$ thin films. Biomaterials 23:2545-2552

92. Liu YD, Bao CY, Wismeijer D, Wu G (2015) The physicochemical/biological properties of porous tantalum and the potential surface modification techniques to improve its clinical application in dental implantology. Mater Sci Eng C 49:323-329

93. Li X, Wang L, Yu XM, Feng Y, Wang C, Yang K, Su D (2013) Tantalum coating on porous Ti6Al4V scaffold using chemical vapor deposition and preliminary biological evaluation. Mater Sci Eng C Mater Biol Appl 33:2987-2994

94. Wang J, Li J, Yang HL et al (2012) Preparation and properties of meshwork metal by foam impregnation. J Cent S Univ (Natural Science Edition) 43:1684-1689

95. Balla VK, Bodhak S, Bose S, Bandyopadhyay A (2010) Porous tantalum structures for bone implants: fabrication, mechanical and in vitro biological properties. Acta Biomater 6:3349-3359

96. Stiehler M, Lind M, Mygind T, Baatrup A, Dolatshahi-Pirouz A, Li $H$, Foss M, Besenbacher F, Kassem M, Bünger C (2008) Morphology, proliferation, and osteogenic differentiation of mesenchymal stem cells cultured on titanium, tantalum, and chromium surfaces. J Biomed Mater Res A 86A:448-458

97. Bencharit S, Byrd WC, Altarawneh S, Hosseini B, Leong A, Reside G, Morelli T, Offenbacher S (2014) Development and applications of porous tantalum trabecular metal-enhanced titanium dental implants. Clin Implant Dent Relat Res 16:817-826

98. Bencharit S, Byrd WC, Hosseini B (2015) Immediate placement of a porous-tantalum, trabecular metal-enhanced titanium dental implant with demineralized bone matrix into a socket with deficient buccal bone: a clinical report. J Prosthet Dent 113:262-269

99. Edelmann AR, Patel D, Allen RK, Gibson CJ, Best AM, Bencharit $S$ (2019) Retrospective analysis of porous tantalum trabecular metal-enhanced titanium dental implants. J Prosthet Dent 121:404-410

100. Lee JW, Wen HB, Gubbi P, Romanos GE (2018) New bone formation and trabecular bone microarchitecture of highly porous tantalum compared to titanium implant threads: a pilot canine study. Clin Oral Implants Res 9:164-174 
101. Lee JW, Wen HB, Battula S, Akella R, Collins M, Romanos GE (2015) Outcome after placement of tantalum porous engineered dental implants in fresh extraction sockets: a canine study. Int J Oral Maxillofac Implants 30:134-142

102. Macheras GA, Lepetsos $P$, Leonidou AO, Anastasopoulos PP, Galanakos SP, Poultsides LA (2017) Survivorship of a porous tantalum monoblock acetabular component in primary hip arthroplasty with a mean follow-up of 18 years. J Arthroplasty 32(12):3680-3684

103. Sagherian BH, Claridge RJ (2015) Salvage of failed total ankle replacement using tantalum trabecular metal: case series. Foot Ankle Int 36(3):318-324

104. Papacci F, Rigante L, Fernandez E, Meglio M, Montano N (2016) Anterior cervical discectomy and interbody fusion with porous tantalum implant. Results in a series with long-term follow-up. J Clin Neurosci 33:159-162
105. Zhang X, Wang J, Xiao J, Shi Z (2016) Early failures of porous tantalum osteonecrosis implants: a case series with retrieval analysis. Int Orthop 40:1827-1834

106. Romanos GE, Delgado-Ruiz RA, Sacks D, Calvo-Guirado JL (2018) Influence of the implant diameter and bone quality on the primary stability of porous tantalum trabecular metal dental implants: an in vitro biomechanical study. Clin Oral Impl Res 29:649-655

Publisher's Note Springer Nature remains neutral with regard to jurisdictional claims in published maps and institutional affiliations. 